\title{
Socio-economic profile of village bank member in suburban Ankara: microcredit mannequin and assumptions on microfinance market of Turkey
}

\author{
Tomáš Hes*, Alena Neradová**, Karel Srnec ${ }^{\star * *}$ \\ Institute of Tropics and Subtropics, Czech University of Life Sciences Prague, Kamýcká 129, \\ 165 21, Prague 6, Czech Republic \\ *,**,***Tel.: +420 224382164, +420 224382503, +420 224382161 \\ *,*****E-mail address: thes@myelen.com , neradovaa@its.czu.cz , srnec@its.czu.cz
}

\begin{abstract}
Turkey harbours one of the greatest untapped microfinance markets in the world. Despite its enormous dormant potential, few studies were undertaken in order to potrait the socio-economic character of its main protagonist: enterprising mother operating in the suburbs of urban and semiurban environment. The study summarizes result of field research carried out by team of researchers from Czech University of Life Sciences and models a credit mannequin, profiling the average Turkish microfinance client in suburban areas of Central Anatolia. The assemblage enables to depict genuine relationships of mainstream clientele towards selected topics, reaching better understanding of nature and particularities of the Turkish microfinance market and drawing conclusions on its further development.
\end{abstract}

Keywords: credit mannequin; microfinance; funding; Turkey; microcredit; TGMP

\section{INTRODUCTION}

\section{1. Microfinance market in Turkey}

In comparison to neighbouring countries in the South-Eastern Europe and Central Asia, Turkey remains far from reaching its microfinance potential (2). Despite being the biggest economy of the region with a high number of people unable to access banking services through the formal sector (Burritt, 2003), microcredit schemes are rather new in Turkey and only few research studies were undertaken in this field (4).

Turkey is in acute need of microfinance. Statal social policies developed to help those who receive aid within the aid system to become producers have proved insufficient (3). According to OECD Factbook, Turkey belonged to the countries with the worst income distribution among OECD members in 2010, being 29th in terms of inequality, with the Gini coefficient of 0.43 . The same rank hold Turkey in the category of poverty, with $18.08 \%$ of the population living under poverty line (3).

Substantial disparities of income betwen urban and rural environment persist. Sweeping urbanisation increases the interconnected challenges of infrastructure, labour supply, 
healthcare, education and security. Moreover, urbanization without adequate collateral development forms a particular type of markets, escalating due to absence of formal property titles in ,gecekondu" neighbourhoods, leading to formation of informal job markets conformed by unemployed labourers streaming into urbs from the provinces. Microfinance could play important role by reducing migration pressures consisting in stimulation of economic growth and job creation, both in urban and rural settlements.

Notwithstanding the fact that microfinance belongs to the recommended instruments for poverty eradication in Turkey, the sector is in its early stage of development in terms of number of people served as well as of range of services offered (1). The potential of microfinance appears considerable, giving the fact that SMEs account for $99 \%$ of all enterprises in Turkey estimated by $\mathrm{TAC}^{2}$ at 4 million units, with non agricultural SMEs employing more than $40 \%$ of the workforce, and producing $35 \%$ of exports. Access to microfinance would help to decrease vulnerability by enabling microenterprises to take advantage of opportunities, to diversify and to increase sources of income (11).

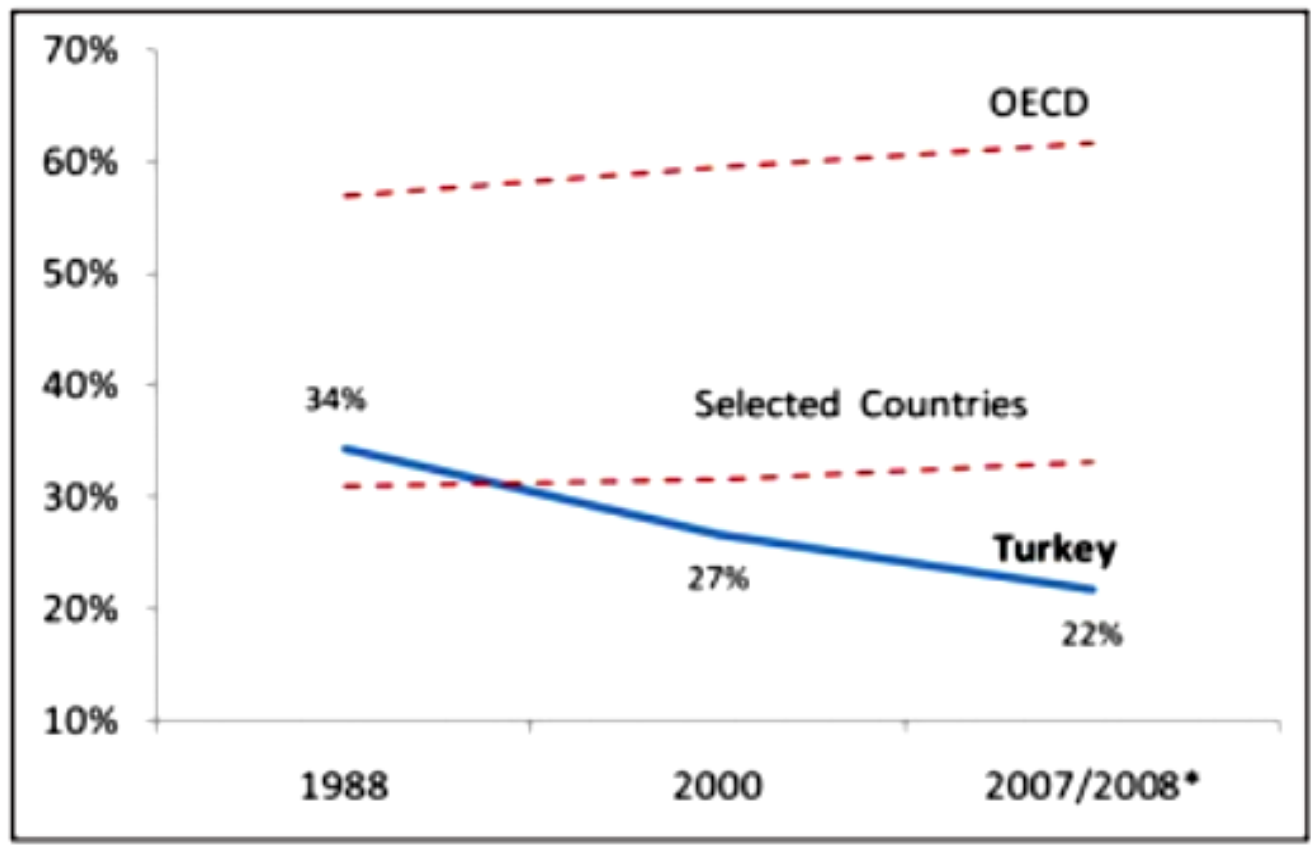

Source: Dayioglu and Kirdar (2009), WDI, TÜiK. OECD Stat Extracts. *Latest available year.

Fig. 1. Comparison of female labor participation rates development trend in Turkey and OECD countries, 1988-2008.

In particular microfinance ought to become an empowering platform for a country with low rate of women participating in the labor force, which constitutes another questionmark related to Turkey in relation to microfinance. Suprisingly, significant structural and social changes of recent decades did not facilitate more women to enter the labor markets, although

\footnotetext{
${ }^{1}$ Gecekondu is a Turkish word meaning a house put up quickly without proper permissions. The gecekondu phenomenon is linked with the problems of unemployment and poverty, especially in the east of the country. ${ }^{2}$ Tradesmen and Artisans Confederation
} 
women are becoming more educated, getting married at a later age and the social attitutes toward working spouses has changed, while fertility rates are declining. Despite these factors, the share of women seeking or having jobs is on decrease, from $34.3 \%$ in 1988 to $22 \%$ in 2008, which is the opposite trend than occurring among OECD countries (13).

The lack of quality information on microfinance, lack of regulatory framework combined with little understanding on microfinance among government, NGOs and private sector and deficient legal infrastructure for new microcredit initiatives are the top reasons for lack of development of the sector (5). Disregarding EIF funded $\mathrm{CIP}^{3}$ initiatives and stateowned Halk Bank and Ziraat Bank, providing individual loans to SMEs with average loan sum higher than 1,000 USD, the main providers of classical microcredit in Turkey are currently two MFIs, Maya and TGMP, serving loans mostly to female microentrepreneurs operating in the informal sector, with average loan size of about 350 USD (3).

\section{2. Grameen Microfinance Project (TGMP)}

In June 2003, the Foundation for Waste Reduction launched the Turkish Grameen Microfinance Project (TGMP) which applies the Grameen village bank microcredit methodologies of loans to poor people without collateral. TGMP became principal partner for the survey project being a prime Turkish MFI with substantial experience gathered, operating throughout the country and offering standartized product countrywide. TGMP provides microcredits ranging between 200-600YTL (150-350 US\$) with an interest rate of $20 \%$ p.a.a which are distributed on the basis of solidarity groups consisting of five to ten women. The group members are equally accountable for the repayment of loans. The credit receivers use the credits mostly in home-based activities such as raising livestock, petty retail commerce, sewing, and offering other handicraft or small marketing activities in the neighbourhood. The credit programs require borrowers to form groups in which all borrowers are jointly liable for each other's loans. The creation of peer group pressure among the group members encourages each individual in the group to repay her debts regularly enabling the micro credit program to achieve high repayment rates of 98 percent (Rahman 1999). As of October 2012, TGMP operated 94 branches throughout Central and Eastern Turkey, with 60,641 members registered and 183,728 townsands of Turkish lira loaned out by 303 employees ${ }^{4}$.

\section{RESEARCH}

\section{1. Background of the study}

In August - September 2012, research team from Czech University of Life Sciences (CULS) carried out in collaboration with Turkish microfinance institution TGMP and SESRIC $^{5}$, subsidiary organ of the Organisation of Islamic Cooperation (OIC) ${ }^{6}$, a survey of the microfinance clientele in the suburban outskirts of Ankara. Both organizations extended key infrastructure and support of credit officers for the field research. The survey focused on village bank members, the most important segment of microfinance clientele in Turkey, mostly enterprising women operating in suburbs of cities and adjacent conurbanisations. The main objective of the project is to model an average microfinance client on the basis of survey

\footnotetext{
${ }^{3}$ CIP Micro-credit agreement, at present collaborating with Finansbank (5)

${ }^{4}$ http://eng.tgmp.net/, 1th of December 2012

${ }^{5}$ The Statistical, Economic and Social Research and Training Centre for Islamic Countries

${ }^{6}$ Organization of Islamic Conference
} 
data and thus to assess the socio-demographic nature of the core Turkish microfinance clientele.

\section{2. Research justification}

The present knowledge base on microcredit is partial and contested.(Kovsted et al., 2000). The state of the art know-how on microfinance is territorial and non-transferable due to cultural uniqueness of every market, and fragmented into many fields of focus, targeting specific topics, while unable to provide a general picture on the characteristics of average client. For young, culturally homogeneous and untapped markets, just as Turkey is, simulation of a credit mannequin presents a way to produce valuable assumptions opportune for the MFIs determined to offer standartized products to mass market clientele with certain socio-demographic traits, reknitting their strategy according to the acquired knowledge during the initial phase of the market development. Credit mannequin, a term introduced for the first time in this study, represents a simulated client model, displaying its most probable characteristics in order to foresee the behavior of the mass clientele in advance. The objective of this synthesis is thus to apprise the average character of the microfinance clientele in Turkey, in the attempt to find socio-demographic patterns of the debtorship, as well as to define a blueprint of the use of loans, access to finance, past experience and nexus with religion. Summarized, the principal goals of the survey are:

1. To assess the socio-economic profile of the average client participating in a successful microfinance program, classified in six key areas.

2. Define remarkable particularities of the Turkish clientele, in relation to three selected assumptions and validate or rejem these.

3. To provide details concerning the socioeconomic traits of microentrepreneurs' households and sectorial activities estimating the potentials and threats influencing development of Turkish microfinance market.

Furthermore, the study intends to answer the following questions. What can be said about the average socio-demographic household profile of ideal debtor? Does islamic finance present a competition for classical microfinance? Does religion play an important role for the credit takers? What is the access to finance and what experience have clients with microcredit? Are there any determinants for the turkish microentrepreneurs that are exogenous for the allocation of credit, which could be extrapolated for the future build up of microfinance markets?

\subsection{Methodology}

The primary methodology selected for this study has been a qualitative non-longitudinal approach with percentages of responses being the main data used for the verdict on the client characteristics, based on a standardized questionnaire in which qualitative responses are converted into discrete interval variables, examined with standard correlational tools. The questionnaire consisted out of 30 closed format questions of dichotomous, rating scale and close-ended importance types. The selected sample size of the survey was completed by 117 active clients, belonging to the stable core of TGMP portfolio of clients, who answered the questions during weekly ordinary repayment sessions of the TGMP credit groups under the guidance of the credit officer, routinely organised in flats, courtyards or working spaces of the group members. 
The first part of the study architecture describes the involvement of the debtorship with credit, in six layers of interest: demographic, household, religion, credit experience, credit access and credit use. Pre-synthesis extended in the second part follows, depicting a model of average turkish microfinance client through those characteristics belonging to the clients whose answers coincide in $50 \%$ with the answers from all sample members. In the third part of the study, the clients who according to our view share characteristics desirable by a standard MFI are filtered out and assorted. In the fourth part of the study the two profiles are compared, the average $50 \%$ matching profile as well as the desired client profile, in order to obtain credit mannequin profile through profile intersection. The resulting credit mannequin constitutes the most suitable average microcredit client profile in Turkey, ideal target of the MFIs. In the fifth concluding part, we confirm or reject general assumptions and input the credit mannequin into context of current microcredit development in contemporary Turkey, coming to recommendations for expanding/growing microfinance institutions.



Fig. 2. Research architecture.

\section{RESEARCH RESULTS}

\section{1. Classification in six research domains}

In the following table we present the questions in the survey classified in six domains.

Table. 1. Survey questions classified in six research domains

\begin{tabular}{|c|c|c|c|c|c|c|}
\hline Domain & $\begin{array}{l}\text { Nr. of } \\
\text { question }\end{array}$ & Question & $\begin{array}{l}\text { Nr. of } \\
\text { question }\end{array}$ & Question & $\begin{array}{l}\text { Nr. of } \\
\text { question }\end{array}$ & Question \\
\hline \multirow{2}{*}{$\begin{array}{l}\text { Domain A: } \\
\text { Demographic } \\
\text { profile }\end{array}$} & 1 & Sex & 2 & Age & 3 & Marital status \\
\hline & $4 a$ & Children & $4 \mathrm{~b}$ & Number of children & & \\
\hline $\begin{array}{l}\text { Domain B: } \\
\text { Household } \\
\text { profile }\end{array}$ & 5 & $\begin{array}{l}\text { How many people live in the } \\
\text { household? }\end{array}$ & 7 & Where do you live? & 6 & $\begin{array}{l}\text { How many of those who live } \\
\text { in the household are } \\
\text { economically active? }\end{array}$ \\
\hline $\begin{array}{l}\text { Domain C: } \\
\text { Religion } \\
\text { profile }\end{array}$ & 28 & What is your religion? & 29 & $\begin{array}{l}\text { Does religion form important part of } \\
\text { your life? }\end{array}$ & 30 & $\begin{array}{l}\text { Does your religious leader } \\
\text { prevent you from taking } \\
\text { microcredit? }\end{array}$ \\
\hline $\begin{array}{l}\text { Domain D: } \\
\text { Credit } \\
\text { experience }\end{array}$ & $9 \mathrm{a}$ & $\begin{array}{l}\text { Did you use any type of } \\
\text { credit in the past? }\end{array}$ & 10 & $\begin{array}{l}\text { Did you use the possibility to } \\
\text { finance your economic activities } \\
\text { with help of microcredit more than }\end{array}$ & 23 & $\begin{array}{l}\text { Does the fact that your are } \\
\text { taker of microcredit harm } \\
\text { your family / neighbour }\end{array}$ \\
\hline
\end{tabular}




\begin{tabular}{|c|c|c|c|c|c|c|}
\hline \multirow[t]{2}{*}{ profile } & & & & \multicolumn{2}{|l|}{ once? } & relationships? \\
\hline & $9 b$ & $\begin{array}{l}\text { In case you had any type of } \\
\text { credit in the past, what credit } \\
\text { did you take? }\end{array}$ & 13 & $\begin{array}{l}\text { Is frequency of payment of } \\
\text { installments of microcredit for you } \\
\text { better than frequency of other } \\
\text { credits? }\end{array}$ & 25 & $\begin{array}{l}\text { Does the installment } \\
\text { payment meeting influence } \\
\text { your working activities? }\end{array}$ \\
\hline \multirow[t]{2}{*}{$\begin{array}{l}\text { Domain E: } \\
\text { Use of credit }\end{array}$} & 11 & $\begin{array}{l}\text { Do you at present any } \\
\text { oportunity to use any other } \\
\text { type of credit? }\end{array}$ & 17 & $\begin{array}{l}\text { Does microcredit solve your } \\
\text { financial situation? }\end{array}$ & 19 & $\begin{array}{l}\text { Is your microcredit a } \\
\text { groupcredit? }\end{array}$ \\
\hline & 12 & $\begin{array}{l}\text { Do you prefer islamic } \\
\text { credit? }\end{array}$ & 18 & $\begin{array}{l}\text { What are you using the microcredit } \\
\text { for? }\end{array}$ & 26 & $\begin{array}{l}\text { Are you holder of more than } \\
\text { once microcredit at the same } \\
\text { time? }\end{array}$ \\
\hline \multirow[t]{3}{*}{$\begin{array}{l}\text { Domain F: } \\
\text { Credit access }\end{array}$} & 14 & $\begin{array}{l}\text { Is microcredit more } \\
\text { expensive than any other } \\
\text { accessible credits? }\end{array}$ & 16 & $\begin{array}{l}\text { Do social / family conventions } \\
\text { prevent you from being a debtor? }\end{array}$ & 21 & $\begin{array}{l}\text { Does microcredit demand in } \\
\text { your village / city exceed the } \\
\text { supply? }\end{array}$ \\
\hline & 15 & $\begin{array}{l}\text { Is it difficult to access } \\
\text { microcredit? }\end{array}$ & 20 & $\begin{array}{l}\text { Does the length of credit period } \\
\text { adress your needs? }\end{array}$ & 22 & $\begin{array}{l}\text { Do you have your own bank } \\
\text { account? }\end{array}$ \\
\hline & 27 & $\begin{array}{l}\text { Do you need digger debt or } \\
\text { are your finance needs fully } \\
\text { covered by microcredit? }\end{array}$ & & & & \\
\hline
\end{tabular}

\section{2. Profile of the client group with responses coinciding in more than $50 \%$ of the sample}

The answers to the questions which coincided in over $50 \%$ and henceforth present significant reference for the nature of microfinance market, were the following ones:

Table 2. List of answers that coincide in over $50 \%$ of the cases.

\begin{tabular}{|c|c|c|c|}
\hline Nr. & Question & Answer & $\%$ of answers \\
\hline 1 & Sex & Woman & 100 \\
\hline 3 & Marital status & Married & 90.60 \\
\hline $4 \mathrm{a}$ & $2-3$ children & yes & 76.79 \\
\hline 8 & Achieved education & basic & 69.83 \\
\hline $9 \mathrm{a}$ & Did you use credit in the past? & Yes & 53.40 \\
\hline 17 & Does microcredit solve your financial situation? & Yes & 87.13 \\
\hline 22 & Do you have your bank account? & No & 73.53 \\
\hline 23 & $\begin{array}{l}\text { Does the fact that you are taker of microcredit harm your family } \\
\text { relationships? }\end{array}$ & No & 96.00 \\
\hline 24 & $\begin{array}{l}\text { Do you recommend your economic active neighbours to take } \\
\text { microcredit? }\end{array}$ & Yes & 95.19 \\
\hline 25 & $\begin{array}{l}\text { Does the installment payment meetings influence your working } \\
\text { activities? }\end{array}$ & No & 80.81 \\
\hline
\end{tabular}




\begin{tabular}{|l|l|l|c|}
\hline 26 & Are you holder of more than one microcredit at the same time? & No & 58.59 \\
\hline 27 & Are your financial needs covered by microcredit? & No & 75.76 \\
\hline 29 & Does your religion create important part of your life? & Yes & 92.00 \\
\hline 30 & Does your religious leader prevent you from taking microcredit? & No & 91.00 \\
\hline
\end{tabular}

Concluding, the filtrated answers that coincide in over $50 \%$ of the cases indicate that the microfinance massmarket in urban-semiurban environment in Turkey is formed by clients featured by the following profile traits:

Table 3. Verbal description of client profile through answers coinciding in over $50 \%$ of the cases.

\begin{tabular}{|c|c|c|c|}
\hline Questions & \multicolumn{3}{|c|}{ Profile characteristics } \\
\hline $1,3,4 \mathrm{~A}$ & A woman & married & mother \\
\hline 4B & \multicolumn{3}{|c|}{ with $2-3$ children } \\
\hline 8,9 & with basic education & \multicolumn{2}{|c|}{ with experience with debt in the past } \\
\hline 17 & \multicolumn{3}{|c|}{ declaring that microcredit solves her financial situation } \\
\hline 22,23 & \multicolumn{2}{|c|}{ unbanked } & $\begin{array}{l}\text { stating that microcredit does not harm } \\
\text { family relationships }\end{array}$ \\
\hline $24,25,26$ & $\begin{array}{l}\text { recommending neighbours to } \\
\text { take microcredit }\end{array}$ & $\begin{array}{l}\text { saying that weekly meetings do not } \\
\text { influence her activities }\end{array}$ & with just one microcredit at a time \\
\hline $28,29,30$ & a muslim & $\begin{array}{c}\text { for whom religion is an important } \\
\text { part of her life }\end{array}$ & $\begin{array}{l}\text { while her religious leader does not } \\
\text { prevent her from taking microcredit. }\end{array}$ \\
\hline
\end{tabular}

\section{3. Desired client profile}

Table 4. Desired client answers that coincide in over $50 \%$ of the cases.

\begin{tabular}{|l|l|c|c|}
\hline Nr. & Question & Desired answer & \% of answers \\
\hline 13 & $\begin{array}{l}\text { Is frequency of paying the installments of microcredit for you better than } \\
\text { frequency of other credits? }\end{array}$ & Yes & 84.00 \\
\hline 16 & Do social/ family conventions prevent you from becoming a debtor? & No & 89.11 \\
\hline 23 & $\begin{array}{l}\text { Does the fact that you are taker of microcredit harm your family/ neighbour } \\
\text { relationships? }\end{array}$ & Yes & 96.00 \\
\hline 24 & Do you recommend your economic active neighbours to take microcredit? & No & 58.59 \\
\hline 26 & Are you holder of more than one microcredit at the same time? & \\
\hline
\end{tabular}

In order to establish the profile of most desired or suitable client out from the sample, the answers to selected questions deemed to deliver positive value to a MFI in terms of its desire to include such respondent in its portfolio, were filtered from the the rest. The resulting 
profile is derived from the characteristics of these respondents falling into this category in 100 $\%$ of the answers to selected group of questions. The selection abstains from speculation by choosing only those topics from the survey that undeniably present a simply understandable plus for any MFI, as depicted below.

The clientele that answered in line with the desired answers was separated from the rest and the responses to all survey questions were processed in percentual charts. The responses from those who fall into the desired client profile are presented below in the respective predetermined six domains.

\section{3. 1. Domain 1: Demographic profile of desired clients}

1. Sex

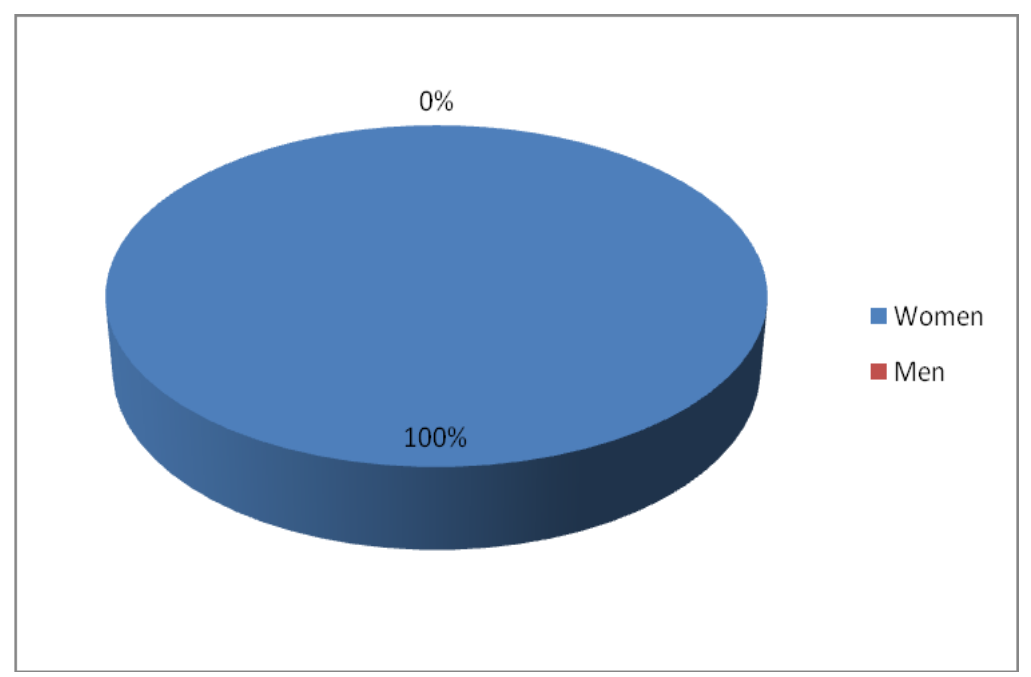

2. Age

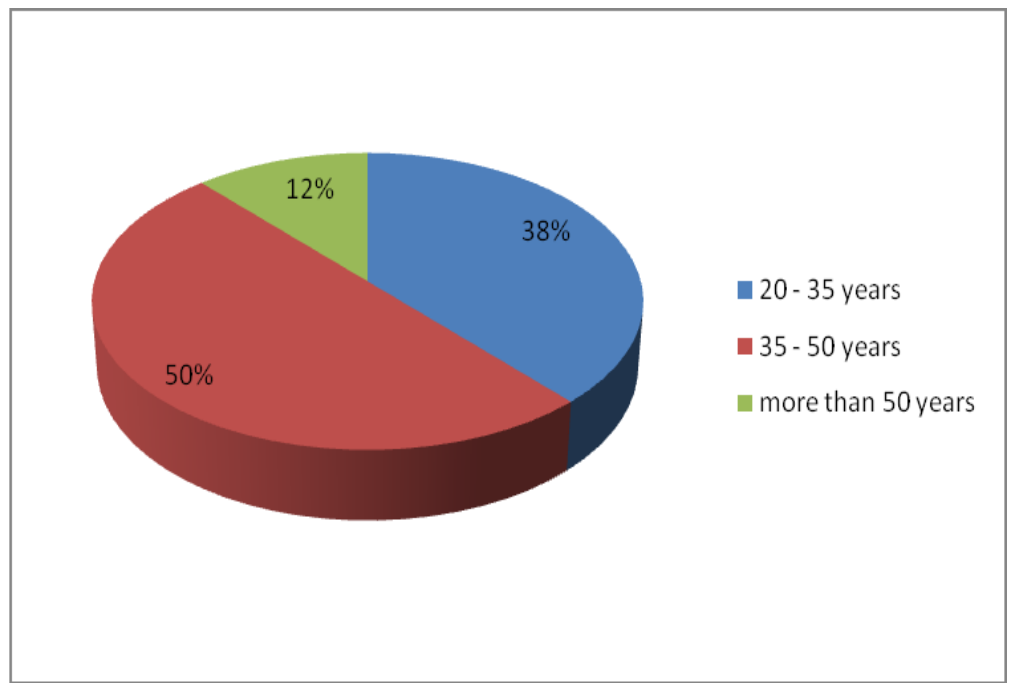

3. Marital Status 


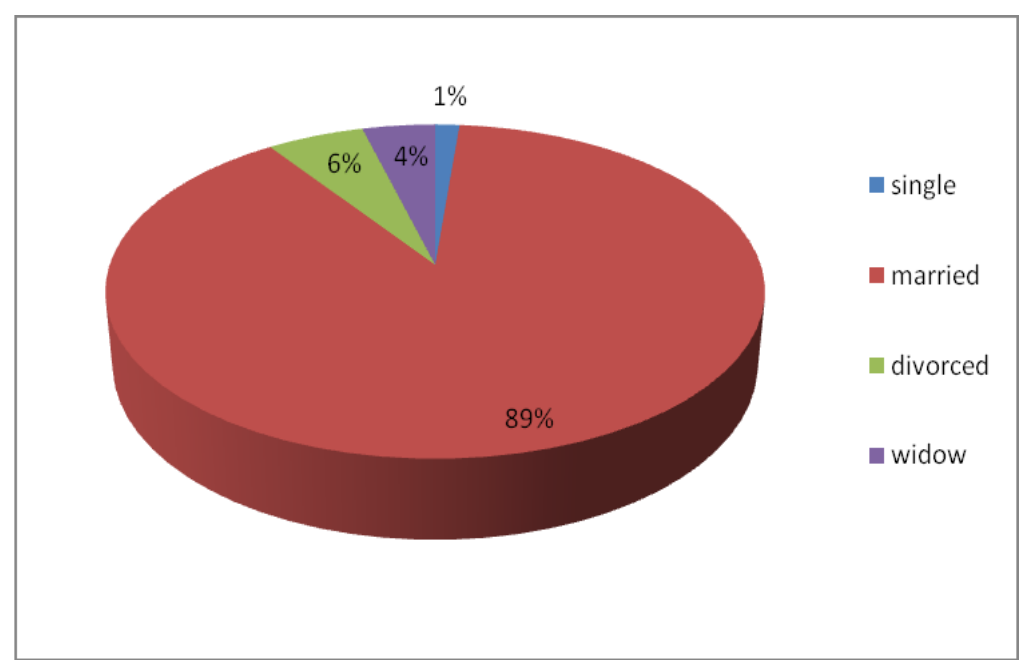

4A Children

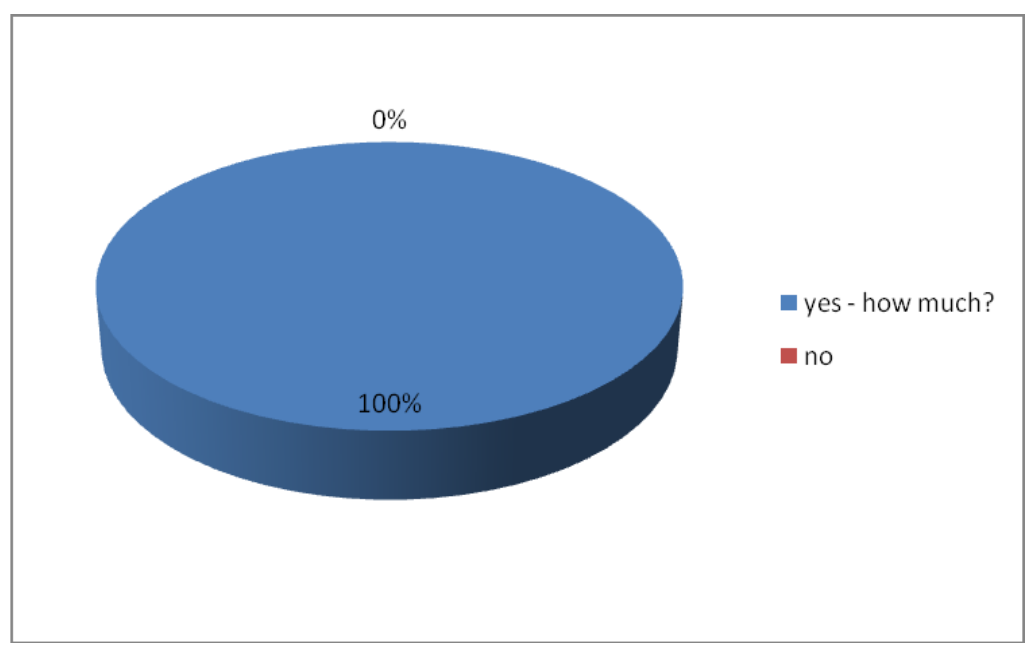

4B Number of children

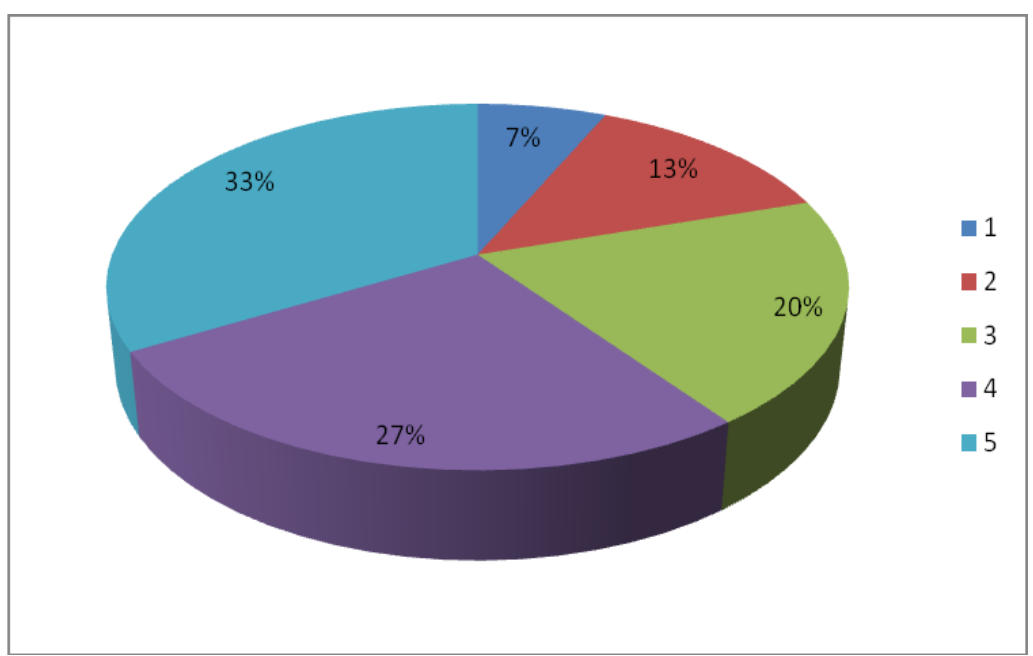

Fig. 2. Demographic profile graphs of desired answers to question 1-4B. 


\section{3. 2. Domain 2: Household of desired clients}

5. People in the household

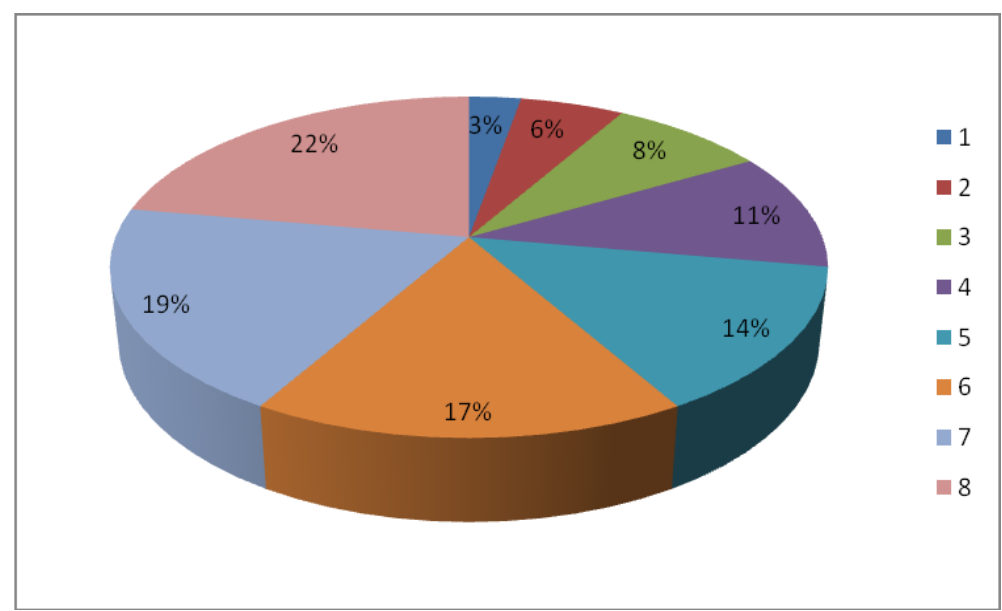

6. Active people per household

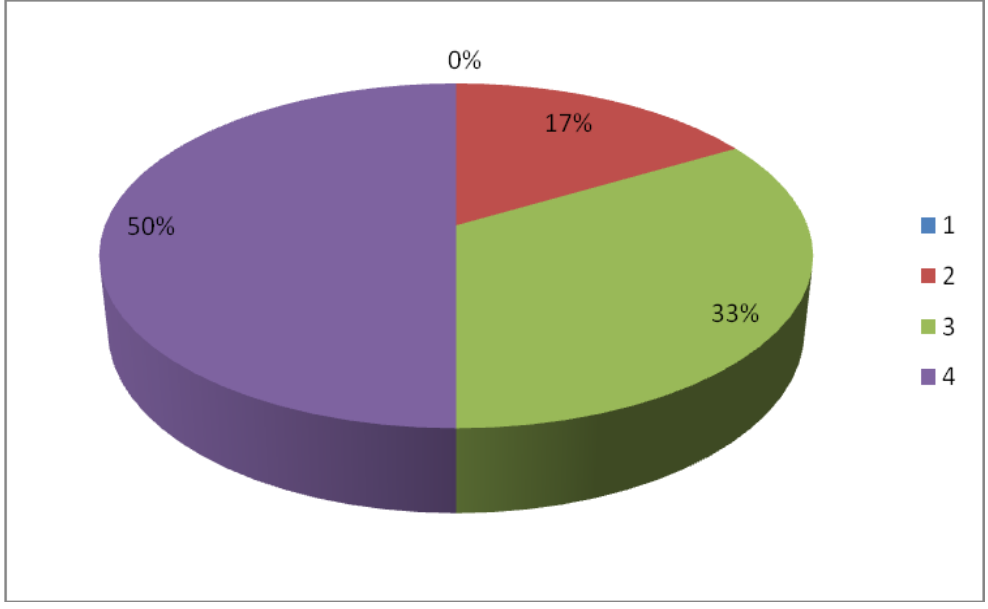

7. Urban / rural

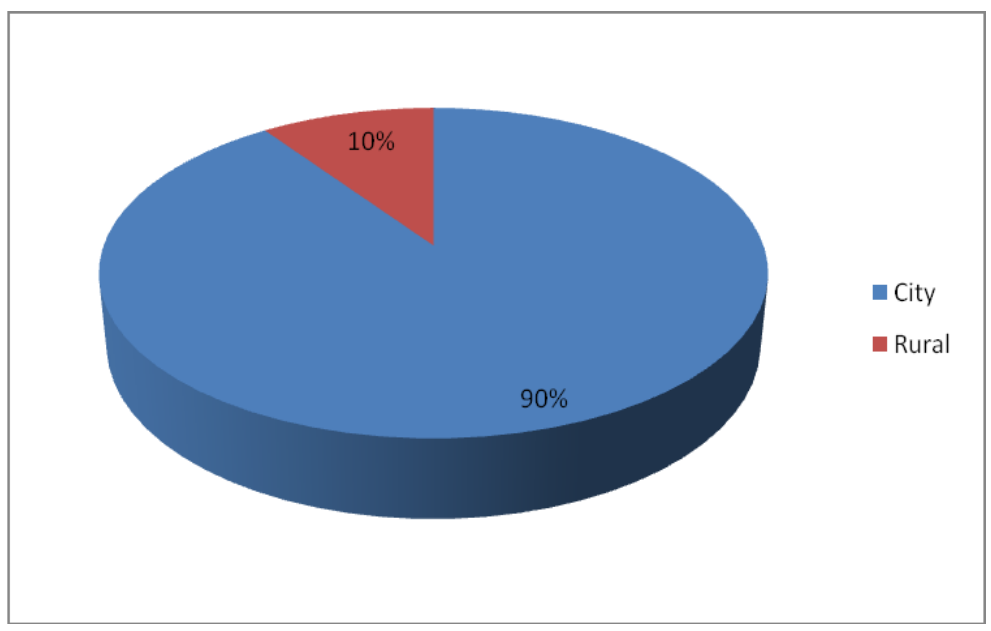

Fig. 3. Household profile graphs of desired answers to question 5-7B. 


\section{3. 3. Domain 3: Religion of desired clients}

28. Religion name

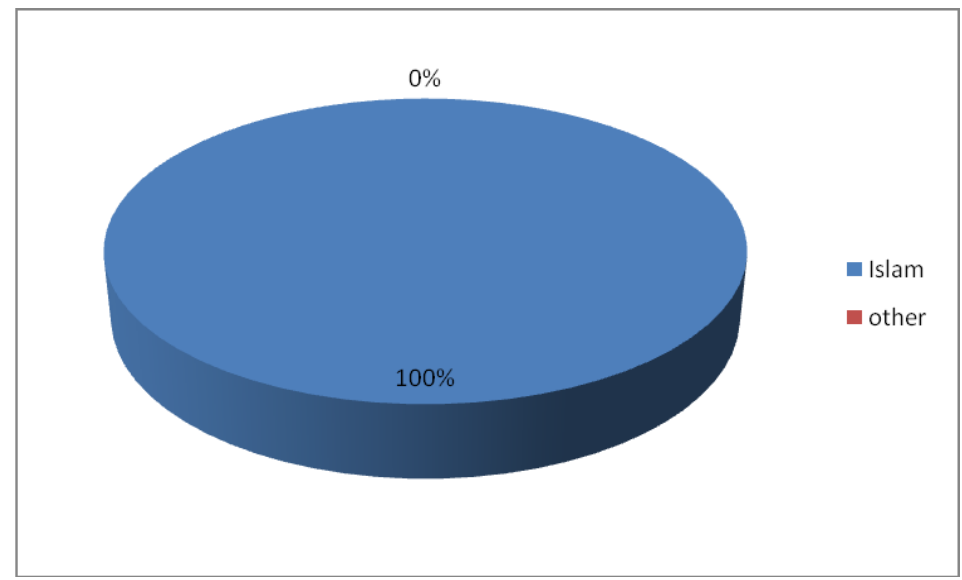

29.Importance of religion

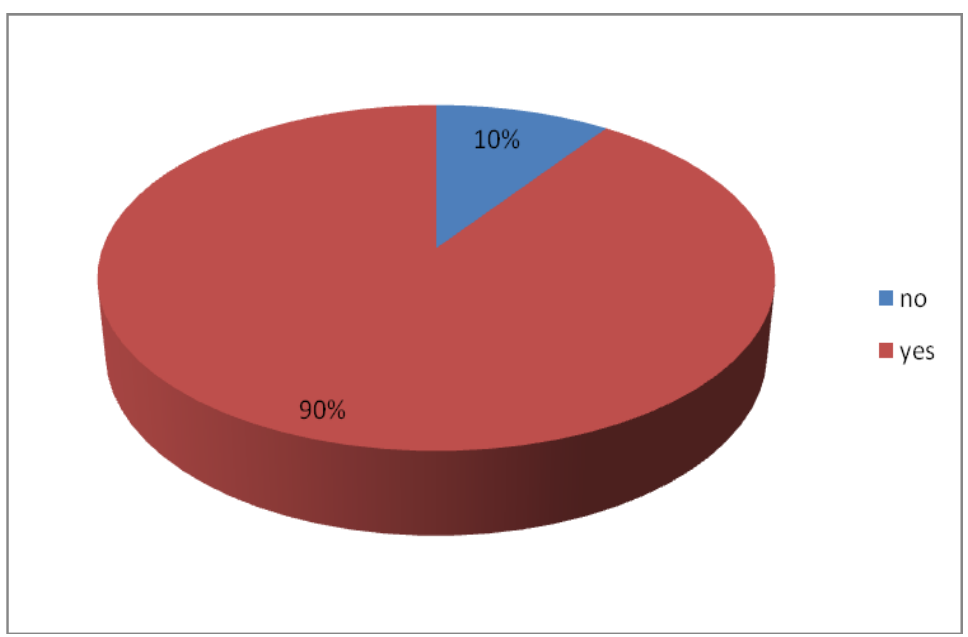

30. Prevention by religious leader

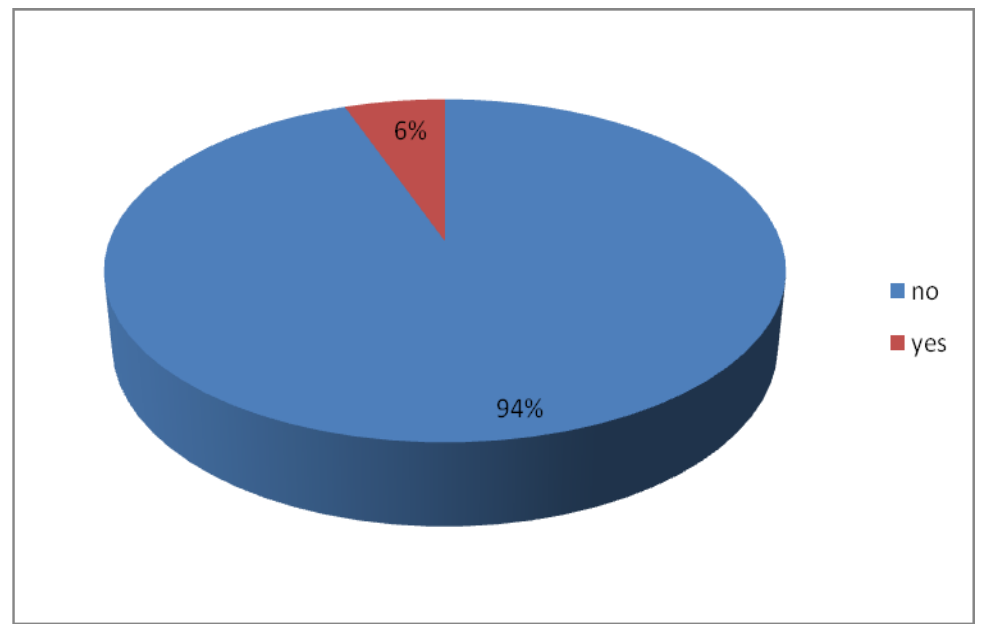

Fig. 3. Religion profile graphs of desired answers to question 28-30. 


\section{3. 4. Domain 4: Credit experience of desired clients}

9A. Credit in the past



9B. What type of credit?

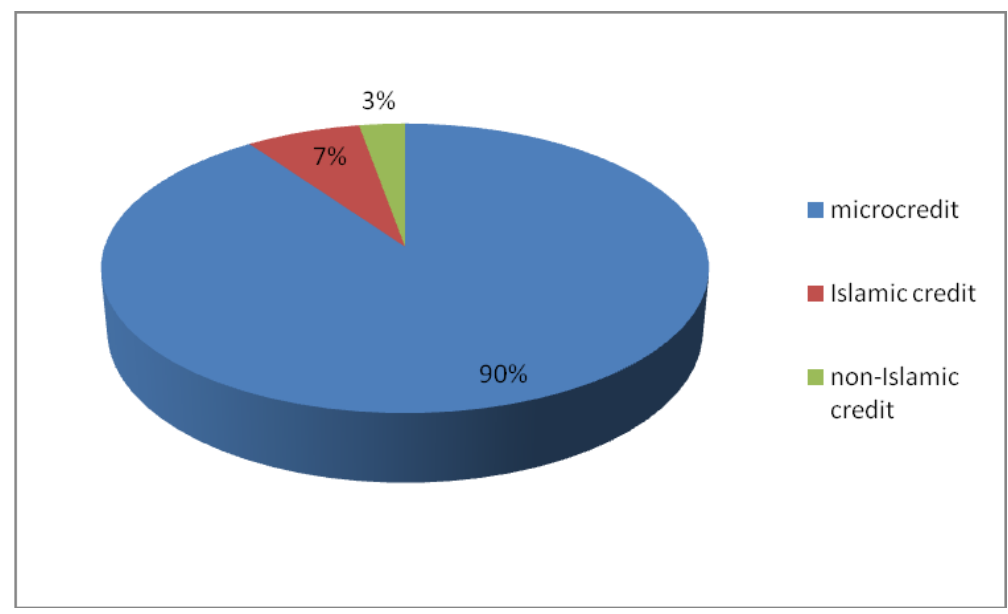

10. Microcredit more than once?

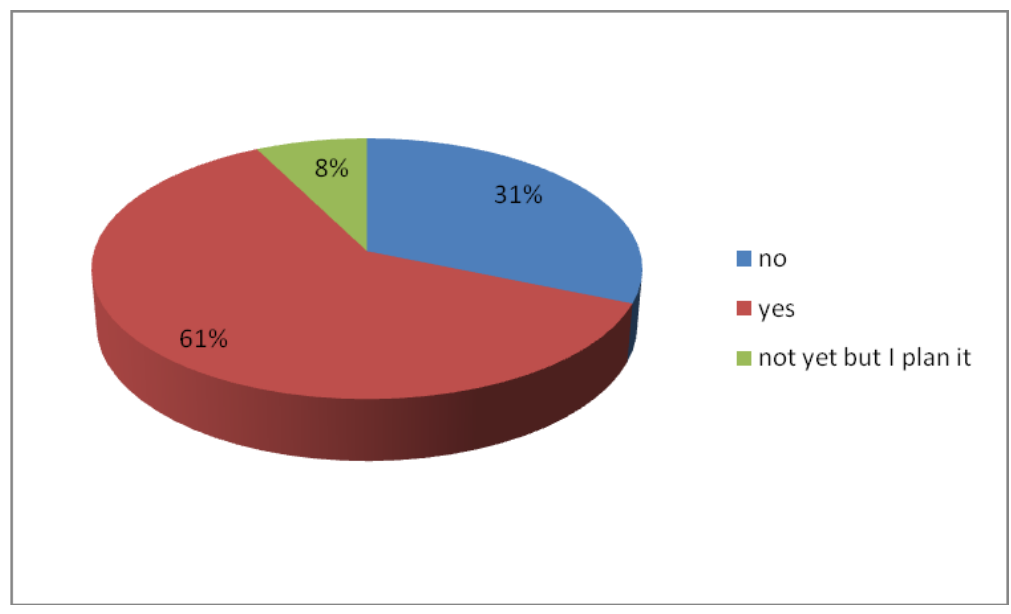

25. Any negative influence for working activities? 




Fig. 4. Credit experience profile graphs of desired answers to question 9A-10 +25 .

\section{3. 5. Domain 5: Use of credit of desired clients}

11. Opportunity for other type of credit?

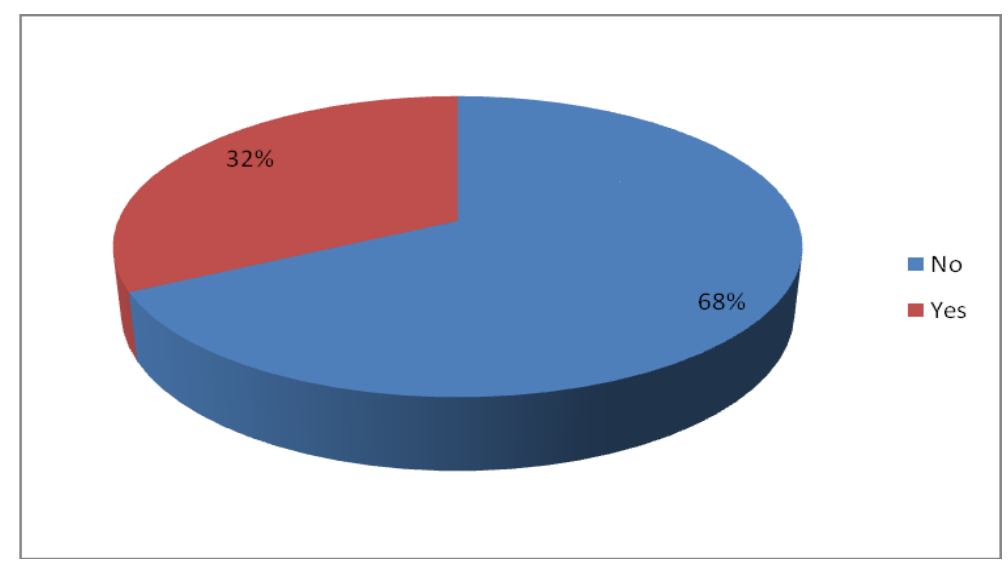

17. Is microcredit a solution?

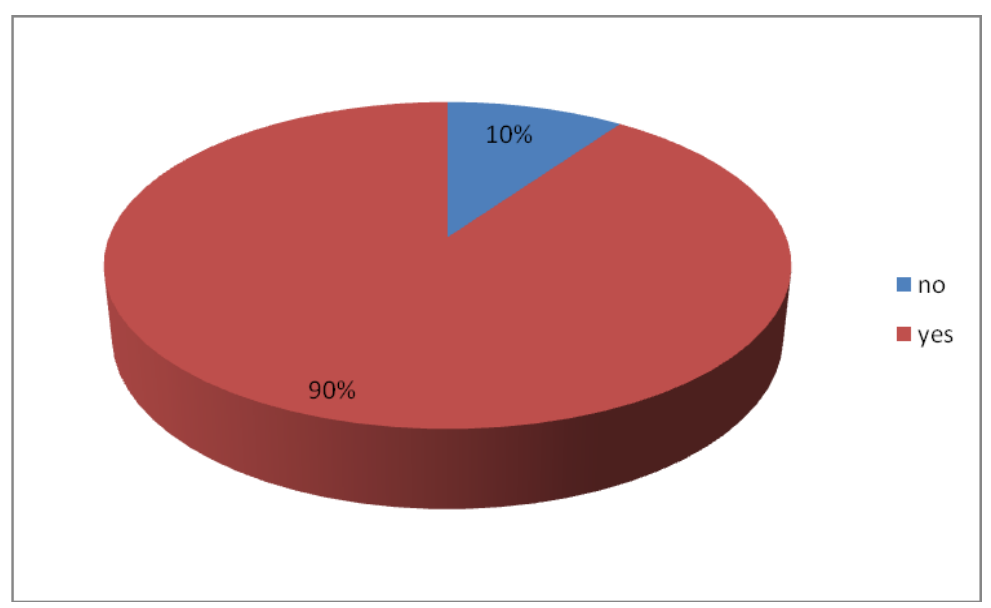

18. Use of credit? 


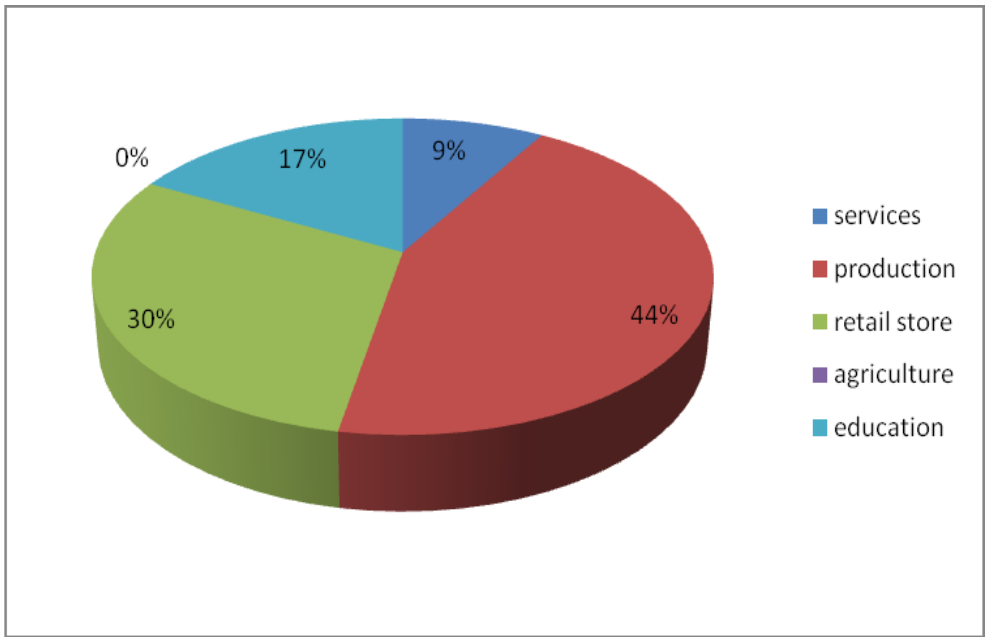

19. Is your microcredit a groupcredit?

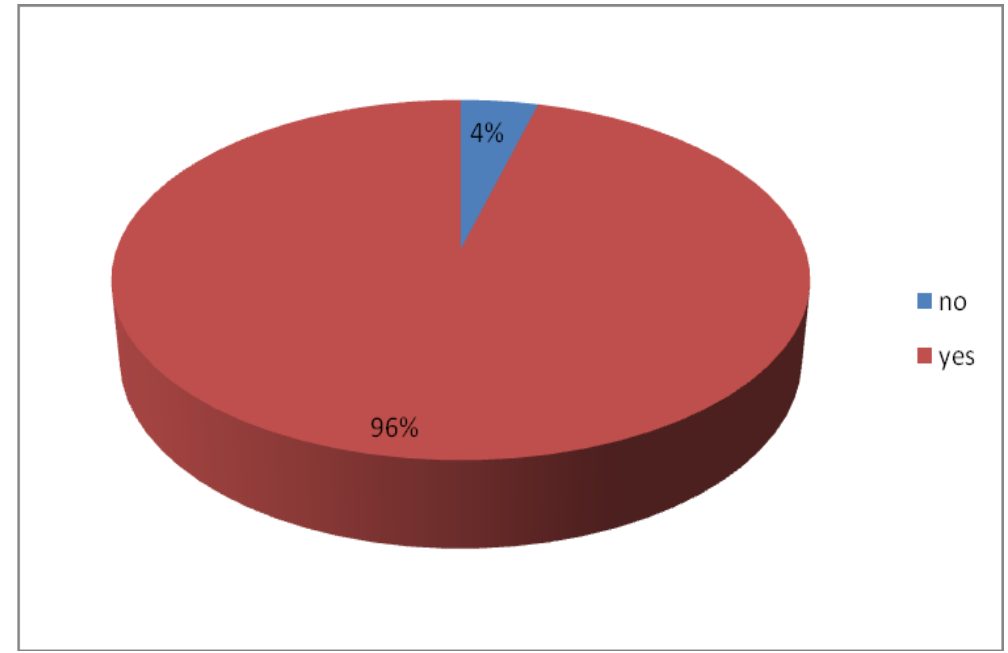

26. Are you holder of more than once microcredit at the same time?

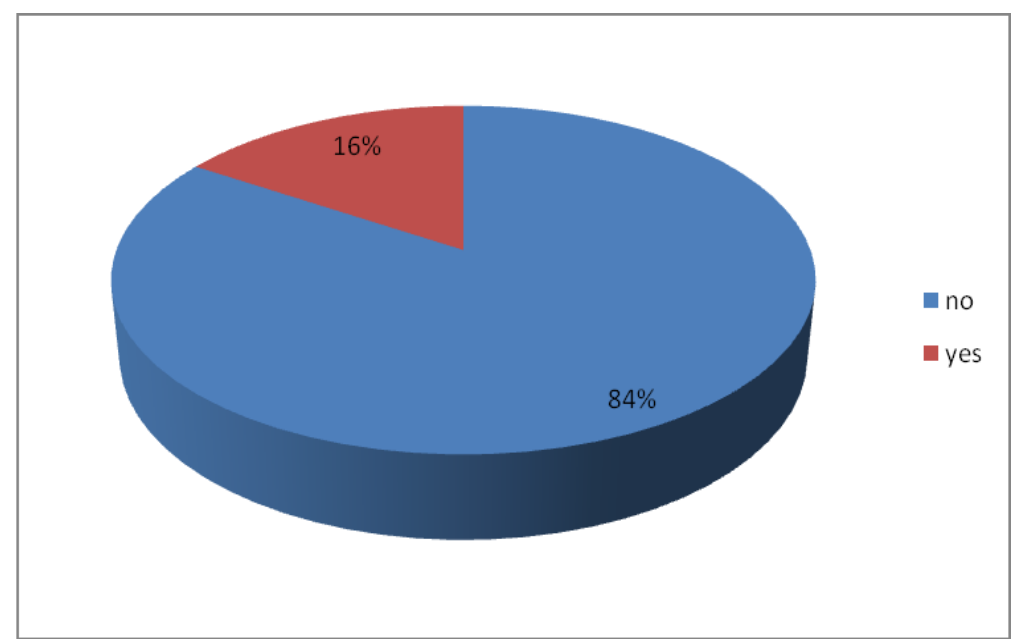

Fig. 5. Credit experience profile graphs of desired answers to question 11,17-19. 


\section{3. 6. Domain 6: Credit access of desired clients}

14. Is microcredit more expensive than other credits?

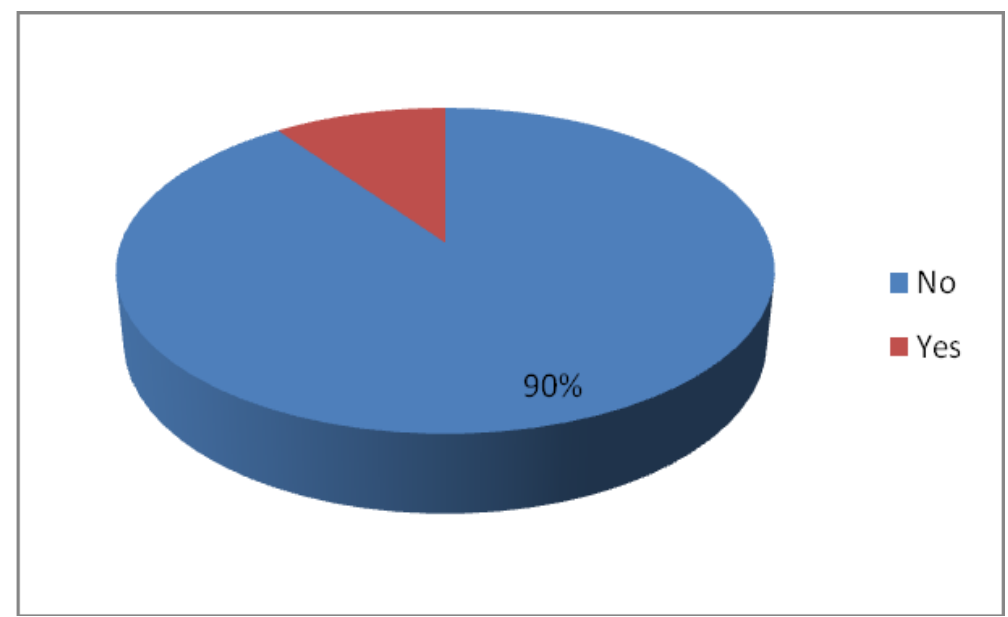

15. Is it difficult to access microcredit?

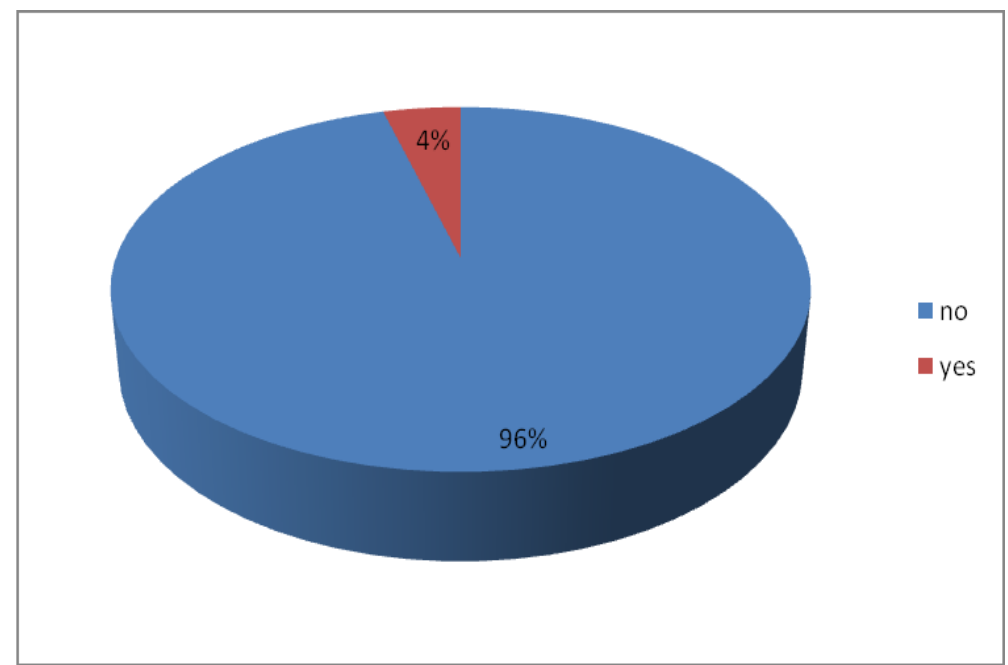

20. Does the length of credit period adress your needs?

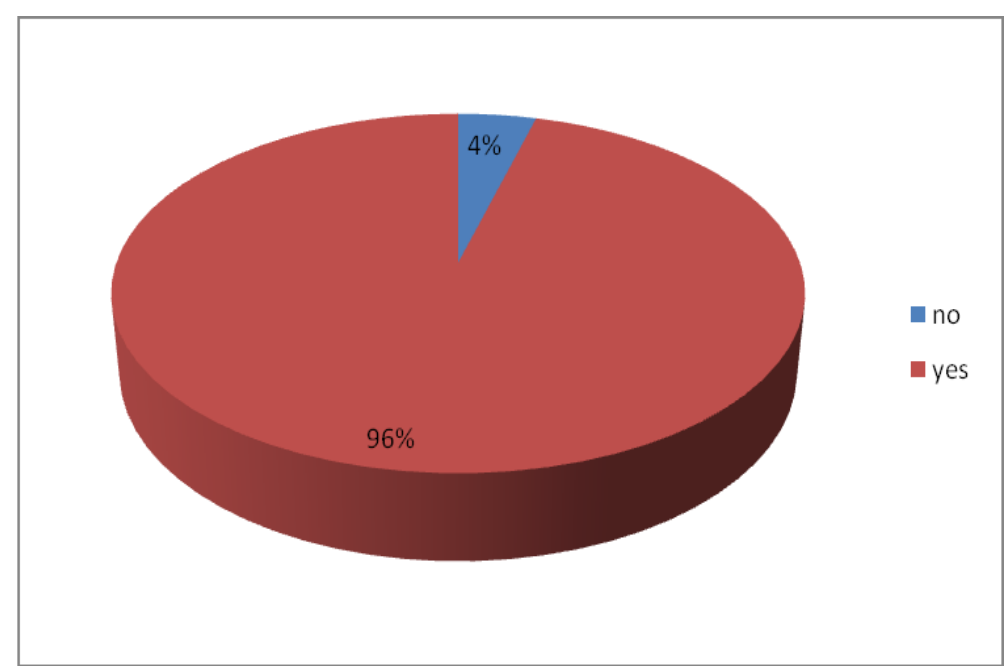

21. Does microcredit demand in your village / city exceed the supply? 


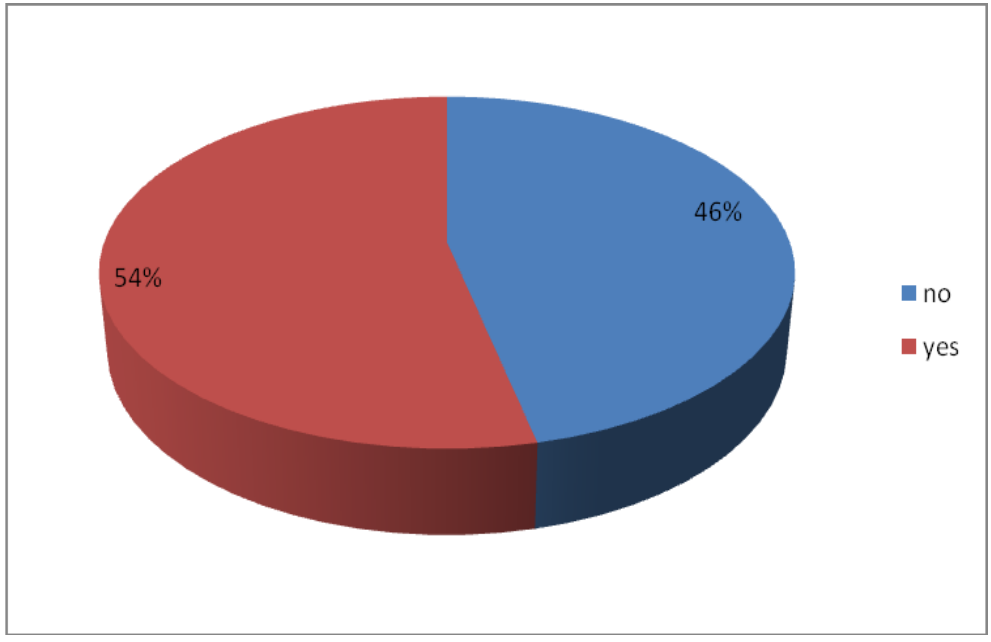

22. Do you have your own bank account?

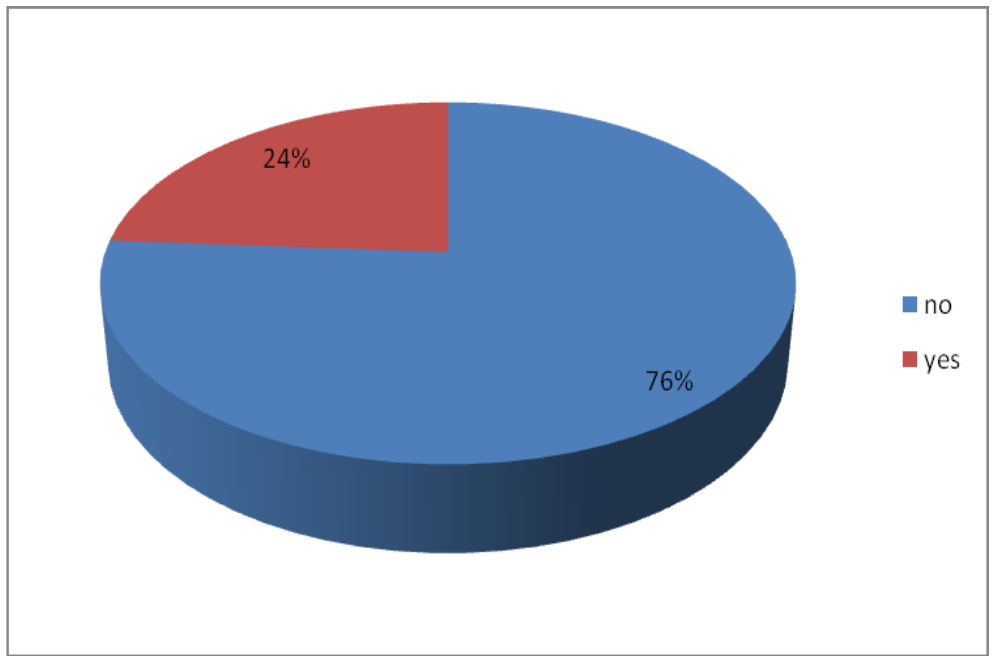

27. Do you need more debt or are your finance needs fully covered by microcredit?

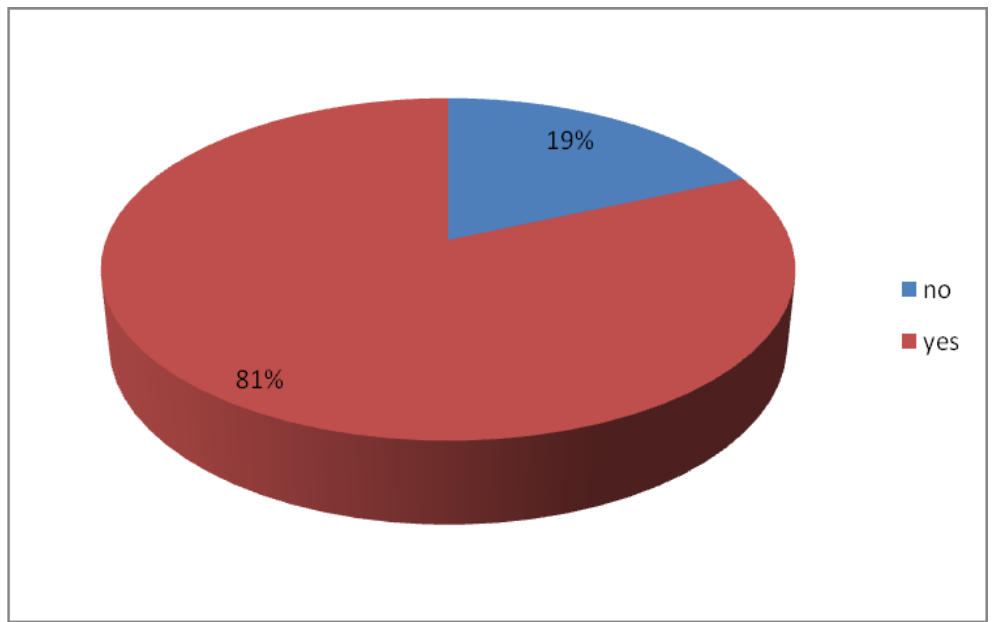

Fig. 6. Credit experience profile graphs of desired answers to question 14,15, 20, 21,22, 27. 


\section{4. Overlapping result: Credit mannequin profile}

We construct the credit mannequin by allowing the $50 \%$ co-incidence profile (3.2.) to intersect with the desired client profile (3.3.), by filtering the answers matrix field through first and through second filter. The result is the following profile of the ideal microfinance client filtered from the real personalities.

Table 5. Credit mannequin profile in verbal description.

\begin{tabular}{|c|c|c|c|c|}
\hline Questions & & Profile char & eristics & \\
\hline $1-4 \mathrm{~A}$ & A woman & aged between 20-50+ & married & mother \\
\hline 4B -7 & with children $2-3$ & $\begin{array}{l}\text { with 3-4 people living in } \\
\text { the household }\end{array}$ & $\begin{array}{l}\text { of out of whom } 2 \text { are } \\
\text { economically active }\end{array}$ & living in urban area \\
\hline $8-10$ & with basic education & $\begin{array}{l}\text { with experience with } \\
\text { debt in the past }\end{array}$ & in form of microcredit & but only once \\
\hline 11-15 & $\begin{array}{l}\text { who does not know if there are } \\
\text { other credits available }\end{array}$ & $\begin{array}{l}\text { claiming that frequency } \\
\text { of payments is not better } \\
\text { than other credits }\end{array}$ & $\begin{array}{l}\text { and that microcredit is } \\
\text { less expensive than other } \\
\text { types of debt }\end{array}$ & $\begin{array}{l}\text { and that microcredit is not } \\
\text { complicated to access }\end{array}$ \\
\hline 16-19 & $\begin{array}{l}\text { and that social / family } \\
\text { conventions do not prevent her } \\
\text { from becoming a debtor }\end{array}$ & $\begin{array}{l}\text { and that microcredit } \\
\text { solves her financial } \\
\text { situation }\end{array}$ & $\begin{array}{l}\text { using the microcredit for } \\
\text { production and retail } \\
\text { store }\end{array}$ & in form of group credit \\
\hline $20-23$ & $\begin{array}{l}\text { and that the length of } \\
\text { microcredit period doesnot } \\
\text { adress her needs }\end{array}$ & $\begin{array}{l}\text { and that microcredit } \\
\text { demand exceeds supply }\end{array}$ & unbanked & $\begin{array}{l}\text { and that microcredit does } \\
\text { not harm family } \\
\text { relationships }\end{array}$ \\
\hline 24-27 & $\begin{array}{l}\text { who recommends neighbours } \\
\text { to take microcredit }\end{array}$ & $\begin{array}{l}\text { while weekly meetings do } \\
\text { not influence her } \\
\text { activities }\end{array}$ & $\begin{array}{l}\text { with just one } \\
\text { microcredit at a time }\end{array}$ & $\begin{array}{l}\text { who does not need bigger } \\
\text { debt as the needs are } \\
\text { covered by microcredit }\end{array}$ \\
\hline 28-30 & a muslim & $\begin{array}{l}\text { for whom religion is an } \\
\text { important part of her life }\end{array}$ & \multicolumn{2}{|c|}{$\begin{array}{l}\text { and her religious leader does not prevent her from } \\
\text { taking microcredit. }\end{array}$} \\
\hline
\end{tabular}

\section{5. Confirmation / Rejection of assumptions}

\section{5. 1. Assumptions}

We have established three assumptions that call for corroboration due to the particularity of microfinance market in Turkey, which differs from the neighbouring microfinance markets in peculiarity of its state-society relationship, religion-state relationship, original culture and stage of development. Confirmation / rejection of these assumptions will shed more light on the understanding of the microfinance market in Turkey as a whole and help to position credit mannequin into wider market context. The assumptions follow:

A. Islamic credit presents a competition for microcredit of Grameen type.

B. The likelihood of being enrolled in the microcredit programmes in Turkey is correlated with the number of economically active household members, as the pressure for income originates in the family environment.

C. There is a cultural aversion for microcredit in Turkey, due to gender and conservative stands of the traditional socio-economic system of a muslim society. 


\section{5. 1. 1. Analysis of Assumption A: Islamic credit presents a competition for microcredit of Grameen type}

Table 6. Responses to questions 11-14.

\begin{tabular}{|c|l|c|c|}
\hline Nr. & Question & no \% & yes in \% \\
\hline 11 & Do you have opportunity to use any other type of credit? & 58.59 & 31.31 \\
\hline 12 & Do you prefer Islamic credit? & 12.87 & 87.13 \\
\hline 14 & Is microcredit more expensive than any other accessible credits? & 79.21 & 20.79 \\
\hline
\end{tabular}

Answers to the selected questions nr. 11 and nr. 14 in Table 6 indicate that competition between islamic credit and village bank microcredit is negligible in Turkey at present, as majority of the clientele stipulated $(58.59 \%$ and $79.21 \%)$ that not many choices are available, nor other credits are accessible from the point of view of price. The resulting answers to question nr. 12 were interpreted as misunderstood, as the clientele considered the term "islamic credit" a synonym for TGMP microcredit. This mere fact however confirms that Shari'ah-compliant credit related literacy is low.

\section{5. 1. 2. Assumption B: Number of economically active members of the household correlates with clients enrollment potential.}

In order to test the results on interdependence through statistical methods, we apply the Chi-square test, a measure of the discrepancy between the observed results and hypothetically expected results, with the $\mathrm{H} 0$ of no correlation between the group samples.

$$
\chi^{2}=\sum \frac{(\mathrm{O}-\mathrm{E})^{2}}{\mathrm{E}}
$$

$\mathrm{O}=$ the observed value

$\mathrm{E}=$ the expected value

Table 7a. Base for calculation of suitability.

\begin{tabular}{|c|l|c|}
\hline Nr. & Question & Less desired client answer \\
\hline 16 & Do social/ family conventions prevent you from becoming a debtor? & Yes \\
\hline 23 & Does the fact that you are taker of microcredit harm your family/ neighbour relationships? & Yes \\
\hline 24 & Do you recommend your economic active neighbours to take microcredit? & No \\
\hline 26 & Are you holder of more than one microcredit at the same time? & Yes \\
\hline 30 & Does your religious leader prevent you from taking microcredit? & Yes \\
\hline
\end{tabular}


The survey data was input into a table serving the purposes of the analysis, consisting of variables corresponding to number of collected questionnaires, and numbers of economically active people in the household next to suitability mark of the clientele, qualified with marks from -1 to 3 scale, as per answers of every client in the questionnaire, converting qualitative data into quantitative, ordinal data. ${ }^{7}$

Table 7a. Base for calculation of suitability.

\begin{tabular}{|c|l|c|}
\hline Nr. & Question & Less desired client answer \\
\hline 16 & Do social/ family conventions prevent you from becoming a debtor? & Yes \\
\hline 23 & Does the fact that you are taker of microcredit harm your family/ neighbour relationships? & Yes \\
\hline 24 & Do you recommend your economic active neighbours to take microcredit? & No \\
\hline 26 & Are you holder of more than one microcredit at the same time? & Yes \\
\hline 30 & Does your religious leader prevent you from taking microcredit? & Yes \\
\hline
\end{tabular}

According to the result, there is none statistically significant interrelation between the number of economically active people living in the household and the suitability of a microfinance client coming from the household and the assumption B is refuted. In other words, the pressure of extense family background in the household cannot be accepted as a significant statistic force driving people becoming microfinance clients.

Table 7b. Result of $\mathrm{X}_{2}$ test.

\begin{tabular}{|c|c|c|c|}
\hline & Value & df & Asymp. Sig. (2-sided) \\
\hline Pearson Chi-square & 9,118681 & 10 & 0,520879 \\
\hline
\end{tabular}

\section{5. 1. 3. Assumption C: There is a cultural aversion for microcredit in Turkey, due to gender and conservative stands of the traditional muslim society}

Table 8. Base for calculation of Assumption C.

\begin{tabular}{|c|l|r|c|}
\hline Nr. & Question & no in \% & yes in \% \\
\hline 30 & Does your religious leader prevent you from taking microcredit? & 91.00 & 9.00 \\
\hline 16 & $\begin{array}{l}\text { Do social/ family conventions prevent you from becoming a } \\
\text { debtor? }\end{array}$ & 89.11 & 10.89 \\
\hline 23 & $\begin{array}{l}\text { Does the fact that you are taker of microcredit harm your family/ } \\
\text { neighbour relationships? }\end{array}$ & 96.00 & 4.00 \\
\hline
\end{tabular}

\footnotetext{
${ }^{7} 3$ points: desired clients as per 3.3; 2 points: ordinary clients as those not falling into categories of desired / less desired / undesired; 1 point: less desired client who answered 1 of the answers to questions in Table 6; 0 points: undesired client with 2 or more indicated answers to the questions in Table 6.
} 
According the answers recorded in Table 8, the overwhelming majority of more than 89 $\%$ of the customers of MFI do not acknowledge having registered any issues in the family / community surrounding, negatively perceiving the act of becoming debtor of a microfinance institution. The assumption $\mathrm{C}$ thus cannot be confirmed.

\section{CONCLUSION}

The study provides us with a counterfactual opportunity to combine assumptions on the microfinance market in Turkey with the credit mannequin profile derived out of the intersection of two client profiles based on the field data, and to position the profile of the clientele in the context of contemporary microfinance market in Turkey.

The conclusion can be drawn on basis of the survey that there is no significant competition evidence between Islamic Sharia based credit and classical microcredit. Neither can be confirmed that cultural, religious and community based factors interfere nor influence the debtors in using microcredit, by inspiring distress caused by breach of religious beliefs due to use of interest based microfinance. The number of of the family members co-habiting the same household with the debtors seems not to have an important correlational effect either.

The credit mannequin exercise signposts the sector of retail commerce and small scale production as the most promising markets. It evidences little relevance of age and education for active microcredit clientele, neither regards the current price policy, average loan amounts nor weekly repayments as a matter for reconsideration. On the other hand, the 16 weeks repayment period is considered too short. Past experience with credit can be considered an important positive characteristics to be aimed at when defining new clientele, as well as marital and family status showing as preferent clients married women with 2-3 children, with a strong family background being a robust element of solid debtorship.

This study has shown that the microcredit market in Turkey, however it is influenced by many different factors, is centered around a centre of gravity, which is a family circle. It has not identified major hindrances and indicates high level of flexibility in terms of cultural and communitarian limitations, that will enable its autonomous future development. Therefore, by providing stronger support for development of microfinance markets, the Turkey seems to acquire a strong and unused grass root development lever, currently far from reaching its potential.

\section{Biographical notes:}

Mr. Dipl. Kfm. Tomáš Hes, PhD. Student, is a Czech development economist, with focus on microfinance, graduated in IHI Zittau, Germany. His career entails work in consulting, currency exchange, banking, MFIs and education NGOs in Brazil, Germany, Czech Republic, Romania and Mexico. Currently pursues the build-up of myELEN.com infrastructure, Czech peer to peer on-line microfinance lending platform.

Ing. Alena Neradová, Ph.D. student, graduated in Faculty of Economics and Management in Czech University of Life Sciences Prague. At the time of studies she spent two semesters at ESDES, Ecole de management in Lyon, France - marketing and management specialization. Currently, Mrs. Neradová researches and teaches Banking and finance, Microfinance and rural economics and Economics of agriculture and natural resources. Within her work experience she participates in marketing projects and in developing of banking system. 
Mr. Doc.Ing.Karel Srnec, PhD., a Czech economist focused on microfinance, graduated in Czech Agricultural University in Prague. Currently, Mr. Srnec researches and teaches banking, development finance and microfinance on the Institute of Tropics and Subtropics affiliated to Czech Agricultural University in Prague, being member of the board of the institute, with broad experience spanning from agricultural development, Middle East and Africa focused consulting, commercial banking as well as membership in the Czech-Israel chamber of commerce.

\section{References}

[1] Grossman H. (2006), Demand Study for Micro-Finance in Turkey Results from a Field Survey Major Findings, Bankakademie International.

[2] Arasli B. (2011), Is Turkey microfinance investable? Hurriyet Daily News.

[3] Burritt K. (2003), Microfinance in Turkey A Sector Assessment Report, United Nations Development Programme.

[4] Karatas A. (2008), The microcredit strategies for SMES in Turkey in the eu harmonizatıon process, 8th Global Conference on Business \& Economics in Florence.

[5] EIF http://www.eif.europa.eu/what we do/guarantees/news/2012/finansbank.htm (10.12.2012), High demand from Turkish businesses secures more finance from the EU Competitiveness and Innovation Programme.

[6] Elliot I. (2010), Fact Finding Report on poverty and housing in Turkey

[7] TGMP (2.12.2012) Corporate presentation, http://eng.tgmp.net/

[8] Toros A. (2010), How compatible is the turkish population structure with EU Countries? Hacettepe University, Institute of Population Studies.

[9] Erman T. (2011), Urbanization in a southern context: the transformation of the urban periphery in the case of a Gecekondu neighborhood in Ankara, Turkey.

[10] Ajaz Ahmed Khan et al. (2010), The influence of faith on Islamic microfinance programmes, Islamic Relief Worldwide.

[11] Kovstedt J. (2009), Synthesis of impact evaluations of microcredit evaluation Study, Centre for Economic and Business Research Porcelćnshaven.

[12] Kandemir O., Aktas Y. (2011), Important of microcredit in fight against poverty in Turkey, International Journal of Economics and Finance Studies, 3(2): 253-262.

[13] World Bank (2009), Female Labor Force Participation in Turkey: Trends, Determinants and Policy Framework. 